\title{
PEMBUATAN KEJU NABATI DARI KEDELAI MENGGUNAKAN BAKTERI ASAM LAKTAT YANG DIISOLASI DARI DADIH
}

\section{PRODUCTION OF NON-DAIRY CHEESE FROM SOYBEAN USING LACTIC ACID BACTERIA ISOLATED FROM DADIH}

\author{
Khaswar Syamsu*) dan Kartika Elsahida \\ Departemen Teknologi Industri Pertanian, Fakultas Teknologi Pertanian, IPB \\ Kampus IPB Dramaga, Bogor 16680, Indonesia \\ Email: khaswars@yahoo.com
}

Makalah: Diterima 13Februari 2018; Diperbaiki 10Juni 2018; Disetujui 23 Juni 2018

\begin{abstract}
Cheese generally has limitations to be consumed by people with milk protein allergies and vegetarian. Besides the price is relatively expensive, the fat content of cheese is also high. Proteins in soybean may be an alternative to protein of milk in cheese making because it has a protein content of which is not much different as well as a low fat content. The use of lactic acid bacteria from dadih as probiotic bacteria with the addition of food additives should be made to improve the quality of non-dairy cheese. This study aimed to determine the formulation of non-dairy cheese made from soybeans with the right flavor concentration which is able to resemble the dairy cheese and to evaluate its characteristics. The design used was a completely randomized factorial design. The types of treatments given were the type of soy milk, percentage of inoculum, and concentration of flavor added. Types of soy milk used were a commercial soy milk powder and fresh soy milk with percentages of inoculum 5\%,10\% , and $15 \%(\mathrm{v} / \mathrm{v})$ as well as the addition of cheese flavor concentrations of $0.5 \% ; 0.7 \% ; 0.9 \% ; 1.1 \%$; and $1.3 \%(w / v)$. Data were analyzed by ANOVA followed by Duncan test if it showed significant differences. A Not A Test showed that the addition of cheese flavor $0.9 \%(w / v)$ and as much as $15 \%$ $(w / v)$ the amount of inoculum in fresh soy milk produced not significantly different smells with commercial dairy cheese at 95\% confidence level. Non-dairy cheese produced can be classified as a semi hard cheese and skim cheese as seen from MFFB (moisture fat free basis) and FDM (fat in dry matter). Characteristics of non-dairy cheese produced were the water content of 66.3\%; ash content of $3.27 \%$; protein content of $26.74 \%$; and the fat content of $0.36 \%$.
\end{abstract}

Keywords : dadih,lactic acid bacteri, non-dairy cheese, soybean

\begin{abstract}
ABSTRAK
Keju yang dikenal pada umumnya memiliki keterbatasan untuk dikonsumsi oleh penderita alergi protein susu dan vegetarian. Selain harganya yang relatif mahal, kandungan lemak pada keju juga tinggi. Protein pada kedelai dapat menjadi alternatif pengganti protein dari susu pada pembuatan keju karena memiliki kadar protein yang tidak jauh berbeda serta kadar lemak yang lebih rendah. Penggunaan bakteri asam laktat dari dadih sebagai bakteri probiotik dengan penambahan bahan tambahan pangan perlu dilakukan untuk memperbaiki mutu dari keju nabati. Penelitian ini bertujuan menentukan formulasi pembuatan keju nabati berbahan baku kedelai dengan konsentrasi perisa keju yang tepat sehingga mampu menyerupai keju hewani, serta mengetahui karakteristiknya. Rancangan yang digunakan adalah Rancangan Acak Lengkap Faktorial. Jenis perlakuan yang diberikan adalah jenis susu kedelai, persentase inokulum, dan konsentrasi perisa keju yang ditambahkan. Jenis susu kedelai yang digunakan adalah susu kedelai bubuk komersial dan susu kedelai segar dengan persentase inokulum 5\%, 10\% , dan 15\% (v/v) serta konsentrasi penambahan perisa keju $0,5 \% ; 0,7 \% ; 0,9 \% ; 1,1 \% ;$ dan $1,3 \%$ (b/v). Data dianalisis dengan ANOVA dilanjutkan dengan uji Duncan apabila menunjukkan pengaruh yang nyata. Uji A Bukan A menunjukkan bahwa penambahan perisa keju 0,9\% (b/v) dengan jumlah inokulum sebanyak $15 \%$ (v/v) pada susu kedelai segar menghasilkan aroma yang tidak berbeda nyata dengan keju komersial pada tingkat kepercayaan 95\%. Dilihat dari aspek MFFB (moisture fat free basis) dan FDM (fat in dry matter), keju nabati yang dihasilkan tergolong kepada semihard cheese dan skim cheese. Karakteristik dari keju nabati yang dihasilkan yaitu kadar air 66,3\% ; kadar abu 3,27\%; kadar protein 26,74\%; dan kadar lemak 0,36\%.
\end{abstract}

Kata kunci : bakteri asam laktat, dadih,keju nabati, kedelai

\section{PENDAHULUAN}

Keju merupakan produk olahan pangan yang dibuat dari bahan baku susu hewani. Susu merupakan salah satu sumber protein bagi manusia yang dikonsumsi di seluruh dunia. Protein pada susu hewani adalah kasein yang merupakan komponen yang menggumpal pada keju. Namun sayangnya tidak semua segmen bisa menikmati dan merasakan manfaat dari keju. Selain harganya yang relatif

*Penulis Korespodensi 
mahal, kandungan lemak dalam keju juga tinggi yaitu sekitar 20-25\% (Anonim, 2016), serta adanya keterbatasan penderita alergi protein susu dalam mengonsumsi produk olahan dari susu sapi. Selain itu, masyarakat vegetarian juga akan menghindari konsumsi keju hewani.

Kedelai merupakan salah satu sumber protein nabati yang apabila dibandingkan dengan protein susu sapi $(3,2 \%)$, protein pada kedelai yang telah diproses menjadi susu kedelai memiliki kandungan protein yang melebihi protein susu sapi yaitu 3,5\% (Alveanita, 2016). Kandungan protein yang tinggi dan rendah lemak pada kedelai berpotensi menjadi bahan baku keju nabati (nondairy cheese).

Proses produksi pembuatan keju pada umumnya yang menggunakan enzim rennet tidak bisa diaplikasikan pada pembuatan keju dari kedelai karena protein kedelai tidak mengandung kasein (Li et al., 2013). Namun proses pembuatan keju nabati dapat menggunakan bakteri asam laktat untuk menggumpalkan protein kedelai dan membentuk aroma pada keju nabati. Menurut Usmiati et al (2011), penggunaan starter dengan bakteri campuran mampu meningkatkan aroma (flavour) pada produk yang dihasilkan. Salah satu sumber pangan fungsional yang memiliki berbagai jenis bakteri yang tumbuh adalah dadih (Usmiati dan Risfaheri 2012). Bakteri asam laktat yang terdapat pada dadih terdiri atas 36 galur dari Lactobacillus, Streptococcus, dan Lactococcus (Usmiati et al., 2011). Selain itu, penambahan bahan tambahan pangan berupa perisa (flavour) keju dalam memproduksi keju nabati (non-dairy cheese) diperlukan agar dapat menyerupai keju pada umumnya.

\section{BAHAN DAN METODE}

\section{Bahan dan Alat}

Bahan yang digunakan untuk pembuatan keju terdiri atas kedelai yang diperoleh dari Koperasi Produsen Tahu Tempe Indonesia (KOPTI Bogor), dadih dari Sumatera Barat, susu kedelai bubuk, natrium bikarbonat, media nutrient agar (NA), skim milk, dan perisa keju (cheese flavour). Bahan yang digunakan untuk analisis adalah akuades, alkohol 70\%, media de Man's Rogosa Sharp Broth (MRSB), media Bacteriology Agar, media Eosin Methylene Blue (EMB), dan $\mathrm{NaOH} 0,1 \mathrm{~N}$.

Peralatan yang digunakan untuk pembuatan keju nabati terdiri dari blender, juicer, labu Erlenmeyer, waterbath dan inkubator. Alat yang digunakan untuk analisis adalah mikropipet beserta tipnya, pH-meter, cawan petri, dan autoclave.

\section{Penyiapan Bahan}

Proses Pembuatan Susu Kedelai Segar.

Kedelai direndam dalam larutan $0,1 \%$ natrium bikarbonat dengan perbandingan kedelai: larutan $=1: 5(\mathrm{~b} / \mathrm{v})$ selama satu malam. Kemudian dipanaskan hingga suhu $85^{\circ} \mathrm{C}$ selama 10 menit. Kedelai dibilas dengan air bersih dan kulit kedelai dikupas dengan cara meremas-remas dan dicuci dengan air berkali-kali. Biji kedelai yang telah bersih kemudian digiling untuk menghasilkan bubur kedelai dengan menambahkan air panas $\left(95^{\circ} \mathrm{C}\right)$ dengan perbandingan kedelai:air panas $=1: 5(\mathrm{~b} / \mathrm{v})$. Bubur kedelai disaring untuk memisahkan ampasnya sehingga didapat susu kedelai segar (Modifikasi Li et al., 2013)

\section{Proses Pembuatan Susu Kedelai dari Susu Kedelai Bubuk}

Susu kedelai bubuk dilarutkan dalam akuades sebanyak $120 \mathrm{~g} \mathrm{~L}^{-1}$.(Chumcuere et al., 2000).

\section{Isolasi Bakteri Asam Laktat pada Dadih}

Sebanyak $1 \mathrm{~g}$ dadih dilarutkan dalam $9 \mathrm{ml}$ garam fisiologis kemudian diencerkan hingga $10^{-4}$ kali. Sebanyak $1 \mathrm{~mL}$ dipipetkan pada cawan petri yang berisi media nutrient agar. Cawan petri kemudian diinkubasi pada suhu $37^{\circ} \mathrm{C}$ selama 24 jam (Chumcuere et al., 2000).

\section{Pembuatan Kultur Inokulum Keju Nabati (Non- Dairy Cheese) \\ Inokulum kultur disiapkan dengan} menginokulasikan bakteri pada susu skim yang telah disterilisasi. Kemudian diinkubasi pada suhu $37^{\circ} \mathrm{C}$ selama 16-18 jam dan disimpan pada suhu $4^{\circ} \mathrm{C}$. (Chumcuere et al., 2000; Li et al., 2013, dan Miskiyah et al., 2011).

\section{Katakteristisasi Bahan Baku}

Uji yang dilakukan untuk mengetahui karakteristik bahan baku yang digunakan (susu kedelai segar dan susu kedelai bubuk) adalah uji total padatan terlarut metode gravimetri (SNI 066989.27:2004) dan analisis kadar protein (AOAC 2005).

\section{Proses Pembuatan Keju Nabati}

Susu kedelai dipasteurisasi pada suhu $63^{\circ} \mathrm{C}$ selama 30 menit dan didinginkan sampai mencapai suhu $35-40^{\circ} \mathrm{C}$. Tahap selanjutnya ditambahkan inokulum sesuai perlakuan (sebanyak $5 \% \mathrm{v} / \mathrm{v}, 10 \% \mathrm{v} / \mathrm{v}$, dan $15 \% \mathrm{v} / \mathrm{v})$. Susu kedelai kemudian diinkubasi pada suhu $37^{\circ} \mathrm{C}$ selama 16 jam. Curd yang terbentuk kemudian disaring dengan menggunakan kain saring. Keju yang terbentuk digarami sebanyak 2\% (b/v) dan dipres kemudian ditambahkan perisa. (Modifikasi Li et al., 2013). Konsentrasi perisa yang digunakan adalah $0,5 \% \mathrm{~b} / \mathrm{v}$; $0,7 \% \mathrm{~b} / \mathrm{v} ; 0,9 \% \mathrm{~b} / \mathrm{v} ; 1,1 \% \mathrm{~b} / \mathrm{v} ;$ dan $1,3 \% \mathrm{~b} / \mathrm{v}$.

\section{Uji Organoleptik}

Uji organoleptik yang dilakukan adalah uji A Bukan A dan uji Hedonik. Uji A Bukan A dilakukan untuk mengetahui adanya perbedaan 
sensori antara dua produk. Pengujian ini dilakukan terhadap 12 orang panelis terlatih untuk membedakan aroma keju nabati (non-dairy cheese) yang diproduksi dengan keju susu hewani komersial. Uji Hedonik dilakukan terhadap 35 orang panelis tidak terlatih dengan melakukan evaluasi terhadap atribut tekstur, aroma, rasa dan warna dari keju yang telah mengalami tahap pengujian A Bukan A (Setyaningsih et al., 2010).

\section{Uji Karakteristik Kimia}

Analisa proksimat keju nabati yang dilakukan meliputi kadar air, abu, lemak, dan protein (AOAC, 2005). Selama kultivasi dilakukan uji pH dan total asam tertitrasi (TAT) (AOAC, 1995) serta rendemen (Arinda, 2013). Rendemen dihitung berdasarkan perbandingan bobot keju nabati dengan volume awal susu kedelai sebelum dikultivasi. Jenis keju yang dihasilkan ditentukan berdasarkan moisture fat free basis (MFFB) dan fat in dry matter (FDM) (CAC, 1978),

\section{Uji Karakteristik Mikrobiologis.}

Uji mikrobiologis yang dilakukan adalah uji jumlah bakteri asam laktat dan uji bakteri koliform.

\section{Analisis Data}

Rancangan percobaan menggunakan Rancangan Acak Lengkap Faktorial dengan perlakuan yaitu jenis susu kedelai, persentase jumlah inokulum, dan konsentrasi perisa keju yang ditambahkan. Pengujian data dilakukan dengan software SPSS16 untuk melihat keragaman data/ANOVA (analysis of variance) dan apabila didapatkan hasil yang berpengaruh nyata, maka analisis dilanjutkan dengan uji Duncan.

\section{HASIL DAN PEMBAHASAN}

\section{Karakteristik Bahan Baku}

Bahan baku pembuatan keju nabati menggunakan dua jenis bahan baku yaitu susu kedelai segar dan susu kedelai bubuk. Karakteristik dari bahan baku ditunjukkan pada Tabel 1 .

Hasil pengujian menunjukkan bahwa karakteristik dari bahan baku yang digunakan dalam pembuatan keju nabati telah memenuhi kadar protein minimum yang ditetapkan. Kadar protein pada susu kedelai bubuk lebih tinggi dibandingkan dengan kadar protein susu kedelai segar. Perbedaan jenis biji kedelai, proses ekstraksi protein kedelai dan formulasi pada produk akhir sangat mempengaruhi kadar protein dan total padatan pada susu kedelai. Selain itu, total padatan terlarut dari susu kedelai bubuk dan susu kedelai segar terdapat perbedaan karena kandungan pada susu kedelai bubuk yang mengandung maltodekstrin sebesar $40 \%$ sehingga meningkatkan jumlah total padatan yang terlarut pada susu kedelai bubuk ( Ernawati et al., 2014).

\section{Pembuatan Keju Nabati}

Protein pada kedelai didominasi oleh globulin yaitu sekitar 65 sampai $80 \%$ yang akan mencapai titik isoelektrik pada $\mathrm{pH}$ 4,5-5,0 dan sisanya adalah enzim-enzim intraseluler, hemaglutenin, lipoprotein membran dan protein inhibitor. Pada $\mathrm{pH}$ tersebut curd akan terbentuk dan dapat dipisahkan dari whey susu kedelai (Ariani, 2002). Nilai $\mathrm{pH}$ dibawah 4,5 akan menyebabkan aroma dan rasa asam pada keju nabati. Pengaruh lama fermentasi keju nabati terhadap perubahan nilai pH dan total asam tertitrasi pada susu kedelai bubuk dan susu kedelai segar ditunjukkan pada Gambar 1 dan Gambar 2.

Tabel 1. Karakteristik Susu Kedelai

\begin{tabular}{cccc}
\hline Pengujian & Susu Kedelai Bubuk & Susu Kedelai Segar & SNI* \\
\hline Total PadatanTerlarut (mg/L) & 128000,00 & $128 \pm 6,50$ & - \\
Kadar protein $(\%)$ & $6,34 \pm 0,16$ & $3,56 \pm 0,16$ & Minimum $1 \%$ \\
\hline
\end{tabular}

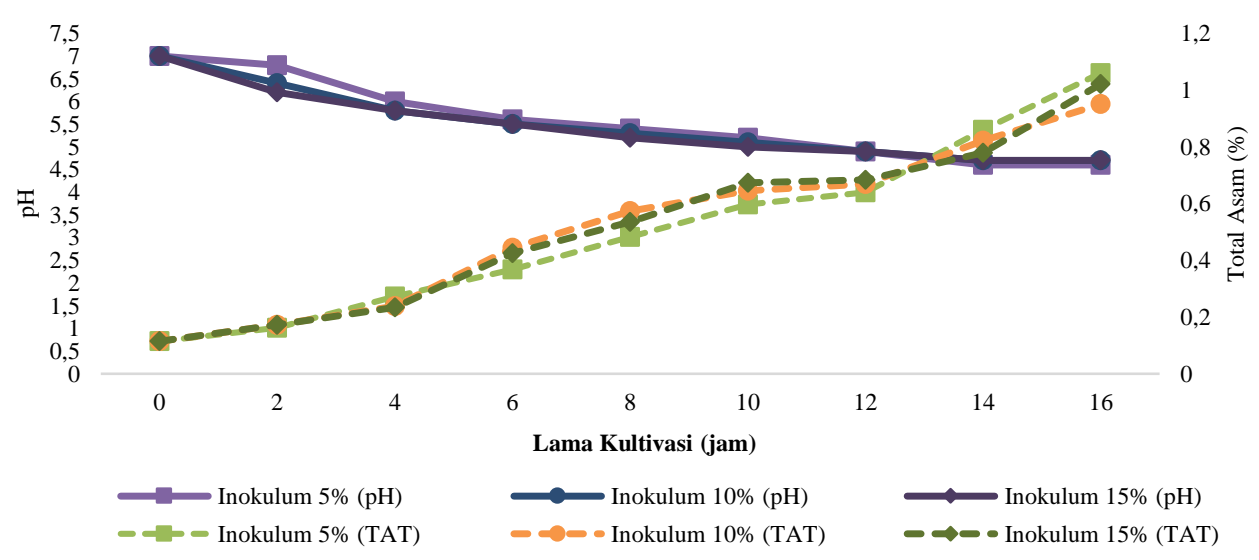

Gambar 1. Pengaruh lama kultivasi terhadap nilai pH dan total asam tertitrasi (TAT) pada susu kedelai bubuk 




Gambar 2. Pengaruh lama kultivasi terhadap perubahan nilai $\mathrm{pH}$ dan total asam tertitrasi (TAT) pada susu kedelai segar

Nilai pH pada susu kedelai bubuk dan susu kedelai segar mengalami penurunan seiring dengan lamanya fermentasi, sedangkan total asam tertitrasi berbanding terbalik dengan nilai $\mathrm{pH}$ dan semakin meningkat seiring dengan lamanya fermentasi. Susu kedelai bubuk mencapai titik isoelektrik pada jam ke-16, sedangkan susu kedelai segar mencapai titik isoelektrik pada jam ke-12.

Kedelai memiliki karbohidrat yang larut dalam air berupa oligosakarida yang terdiri atas sukrosa, stakiosa, dan rafinosa. Bakteri asam laktat memiliki enzim $\alpha$-galaktosidase yang mampu menghidrolisis oligosakarida selama fermentasi berlangsung sehingga mampu menurunkan $\mathrm{pH}$. Ketika $\mathrm{pH}$ tersebut telah mencapai titik isoelektrik dari protein kedelai (globulin), maka terjadilah penggumpalan pada susu kedelai segar ( Hati et al., 2012). Susu kedelai segar tidak memiliki tambahan bahan dalam prosesnya, sehingga akan memudahkan bakteri asam laktat untuk langsung menghidrolis oligosakarida tersebut. Namun, lain halnya dengan susu kedelai bubuk yang memiliki penambahan maltodekstrin. Maltodekstrin merupakan polimer glukosa dari pati yang telah mengalami proses hidrolisis melalui asam atau enzim. Maltodekstrin berfungsi sebagai bahan pengisi, meningkatkan viskositas pada produk, serta mengawetkan makanan. Maltodekstrin untuk makanan pada umumnya memiliki dextrose equivalent (DE) dibawah 20. Hal ini mengakibatkan fermentabilitasnya (kemampuan untuk fermentasi) rendah (Hofman et al., 2016), sehingga titik isoelektrik pada susu kedelai bubuk lebih lama dibandingkan dengan susu kedelai segar.

\section{Rendemen}

Persentase rendemen yang dihasilkan pada setiap konsentrasi inokulumnya ditunjukkan pada Tabel 2.
Tabel 2. Persentase rendemen non-dairy cheese

\begin{tabular}{lcc}
\hline $\begin{array}{c}\text { Bahan } \\
\text { Baku }\end{array}$ & $\begin{array}{c}\text { Jumlah } \\
\text { inokulum }(\%)\end{array}$ & $\begin{array}{c}\text { Rendemen produksi } \\
(\boldsymbol{\%} \mathbf{b} / \mathbf{v})\end{array}$ \\
\hline Susu & 5 & $10 \pm 0,000$ \\
Kedelai & 10 & $14 \pm 0,002$ \\
Bubuk & 15 & $15 \pm 0,002$ \\
& 5 & $14 \pm 0,001$ \\
Susu & 10 & $16 \pm 0,000$ \\
Kedelai & 15 & $17 \pm 0,003$ \\
Segar & & \\
\hline
\end{tabular}

Hasil analisis menunjukkan bahwa jumlah inokulum dan jenis bahan baku yang digunakan berpengaruh nyata $(\mathrm{P}<0,05)$ terhadap rendemen yang dihasilkan. Berdasarkan uji Duncan, rendemen keju nabati dengan konsentrasi inokulum $10 \%$ dan $15 \%$ tidak berbeda signifikan, namun konsentrasi inokulum 5\% dengan konsentrasi lainnya menghasilkan rendemen yang berbeda secara signifikan. Susu kedelai bubuk menghasilkan rendemen yang lebih rendah dibandingkan dengan susu kedelai segar. Keju nabati dari susu kedelai segar memiliki kandungan lemak yang lebih tinggi dibandingkan keju nabati dari susu kedelai bubuk. Kandungan lemak yang tinggi akan berdampak terhadap rendemen yang tinggi pula (Herawati, 2011). Perbedaan kandungan lemak yang dihasilkan dapat dilihat pada Tabel 4. Menurut Spreer (1998), rendemen keju yang dihasilkan dari susu sapi adalah $10 \%$, sedangkan menurut Mullan (2007) rendemen keju cheddar dapat berkisar antara 9-10\%. Rendemen yang dihasilkan pada keju nabati lebih tinggi dibandingkan rendemen dari keju hewani pada umumnya karena dipengaruhi oleh kandungan lemak dan protein didalam bahan yang digunakan (Juniawati et al., 2015) serta tidak adanya proses pemeraman. 


\section{Karakteristik Organoleptik Keju Nabati Uji A Bukan A}

Uji A Bukan A merupakan salah satu jenis uji pembeda yang bertujuan mengetahui perbedaan aroma antara dua produk. Atribut sensori yang dinilai adalah aroma antara keju nabati dengan keju hewani komersial jenis cream cheese. Hal ini diperlukan untuk menilai berapa konsentrasi perisa yang dibutuhkan agar memiliki aroma yang sama dengan keju dari susu hewani. Konsentrasi perisa yang kurang tepat akan menghasilkan aroma langu ataupun aroma yang tidak mengenakkan karena terlalu banyak. Berdasarkan jumlah terkecil untuk menyatakan beda nyata dengan hipotesis berekor dua disimpulkan bahwa aroma sampel pada jumlah inokulum sebesar $15 \%$ dan konsentrasi perisa keju $0,9 \%$ dengan bahan baku susu kedelai segar memiliki kesamaan aroma dengan keju komersial pada tingkat kepercayaan 95\%. Selain itu, terdapat sampel keju nabati dengan bahan baku susu kedelai segar pada jumlah inokulum $15 \%$ dengan konsentrasi perisa keju $0,7 \%$ dan keju nabati berbahan baku susu kedelai bubuk pada jumlah inokulum $15 \%$ dengan konsentrasi perisa keju $1,3 \%$ yang memiliki kesamaan aroma menurut 6 orang panelis. Oleh sebab itu, ketiga sampel tersebut dilanjutkan pada uji Hedonik.

\section{Uji Hedonik}

Uji Hedonik merupakan uji kesukaan yang melibatkan panelis tidak terlatih dengan memilih suatu produk diantara produk lainnya (Setyaningsih et al., 2010). Atribut yang dinilai pada uji hedonik adalah warna, aroma, rasa, dan tekstur dari keju nabati. Nilai rataan hasil uji hedonik ditunjukkan pada Tabel 3.

Sampel dengan bahan baku susu kedelai segar dengan jumlah inokulum $15 \%$ dan konsentrasi perisa sebanyak $1,3 \%$ lebih disukai dari segi aroma, rasa, dan tekstur dibandingkan dengan sampel yang lainnya. Hal ini dapat dilihat dari nilai rataan yang paling tinggi dibandingkan nilai rataan sampel lain. Sedangkan penampakan keju nabati dari susu kedelai bubuk paling disukai dibandingkan dengan penampakan dari keju nabati dari susu kedelai segar.

Hasil analisis data menggunakan ANOVA (Analysis of Variance) menunjukkan bahwa penggunaan jenis bahan baku dan konsentrasi perisa yang berbeda tidak berpengaruh nyata $(\mathrm{P}>0.05)$ terhadap warna dan tekstur dari keju nabati yang dihasilkan. Sedangkan penggunaan bahan baku dan konsentrasi perisa yang berbeda menyebabkan pengaruh yang nyata $(\mathrm{P}<0.05)$ terhadap rasa dan aroma keju nabati. Perisa hanya membantu dalam meningkatkan rasa dan aroma dari keju nabati, tanpa mempengaruhi tekstur dan warnanya.

Berdasarkan uji Duncan yang dilakukan, aroma sampel susu kedelai segar dengan perisa $0,9 \%$ memiliki aroma yang sama dengan susu kedelai bubuk dengan perisa 1,3\%, sedangkan jumlah perisa yang digunakan tidak memberikan pengaruh nyata terhadap rasa keju nabati dari bahan baku yang sama. Bakteri asam laktat mampu menghidrolis protein dan lemak dari susu kedelai. Protein akan dihidrolis menjadi biopeptida dan lemak dihidrolisis menjadi asetaldehid. Biopeptida akan menghasilkan rasa yang pahit pada keju sedangkan asetaldehid akan membentuk aroma yang khas pada keju (Al-Kotami 2015). Oleh sebab itu, aroma akan semakin tajam seiring dengan tingginya kandungan lemak pada keju. Inilah yang menyebabkan aroma pada keju nabati dari susu kedelai bubuk lebih membutuhkan perisa yang lebih banyak dibandingkan keju nabati dari susu kedelai segar karena keju nabati dari susu kedelai bubuk mengandung lemak yang rendah.

\section{Karakteristik Kimia Keju Nabati}

Komposisi nutrien keju nabati dianalisis melalui hasil pengujian kimia yang kemudian diolah untuk mengetahui jenis keju berdasarkan nilai moisture free-fat-basis (MFFB) dan fat content in dry matter (FDM). Hasil analisis komposisi nutrien keju nabati ditunjukkan dalam Tabel 4 yang menunjukkan bahwa penambahan perisa berpengaruh nyata $(\mathrm{P}<0,05)$ terhadap kadar air keju nabati yang dihasilkan sedangkan jenis bahan baku berbeda tidak berpengaruh nyata $(\mathrm{P}>0,05)$ terhadap kadar abu dari keju nabati yang dihasilkan. Perisa keju yang digunakan berbentuk liquid sehingga penambahan konsentrasi perisa akan berdampak pada kenaikan kadar air pada keju nabati. Susu kedelai segar menghasilkan keju nabati dengan kadar protein dan kadar lemak yang lebih tinggi $(\mathrm{P}<0,05)$ dibandingkan keju nabati dari susu kedelai bubuk. Kandungan protein dari keju nabati yang berasal dari susu kedelai bubuk menurun karena lamanya fermentasi untuk mencapai titik isoelektrik dibandingkan dengan susu kedelai segar. Semakin lama fermentasi, maka akan semakin banyak protein yang terdegradasi oleh bakteri asam laktat (Deliani, 2008).

Tabel 3. Nilai rataan uji hedonik keju nabati

\begin{tabular}{ccccc}
\hline \multicolumn{1}{c}{ Perlakuan } & Warna & Aroma & Rasa & Tekstur \\
\hline Susu kedelai segar, inokulum 15\%, perisa keju 0,7\% & $3,51 \mathrm{a}$ & $3,28 \mathrm{a}$ & $2,71 \mathrm{a}$ & $3,17 \mathrm{a}$ \\
Susu kedelai segar, inokulum 15\%, perisa keju 0,9\% & $3,54 \mathrm{a}$ & $\mathbf{3 , 6 3 b}$ & $\mathbf{2 , 8 a}$ & $\mathbf{3 , 3 7 a}$ \\
Susu kedelai bubuk, inokulum 15\%, perisa keju 1,3\% & $\mathbf{3 , 5 7 a}$ & $2,97 \mathrm{~b}$ & $2,2 \mathrm{a}$ & $3,34 \mathrm{a}$ \\
\hline
\end{tabular}

Keterangan : 1 : sangat tidak suka, 2 : tidak suka, 3 : netral, 4: suka, 5: sangat suka

${ }^{a}$ Angka-angka pada kolom yang sama yang diikuti oleh huruf yang sama tidak berbeda nyata pada taraf uji $5 \%$ (uji selang berganda Duncan). 
Keju nabati yang dihasilkan tergolong pada keju semi keras (semihard) tidak matang (unripened/fresh) karena tidak mengalami proses pematangan. Keju semi keras merupakan keju dengan tekstur sedikit lembek, contohnya keju cottage, ricotta, dan jenis lainnya. Hal ini dapat dilihat dari MFFB yang berkisar antara 54-69\% (CAC, 1978). Berdasarkan nilai FDM yang diperoleh, maka keju nabati yang dihasilkan tergolong pada jenis keju skim karena memiliki FDM yang lebih kecil dari 10\% (CAC, 1978).

\section{Karakteristik Mikrobiologis Keju Nabati}

Karakteristik mikrobiologis bertujuan mengetahui populasi bakteri yang terdapat pada produk keju nabati. Uji mikrobiologi yang dilakukan adalah pengujian jumlah bakteri asam laktat (BAL) dan pengujian bakteri koliform untuk mengetahui ada tidaknya bakteri cemaran. Hasil pengukuran populasi BAL dan bakteri koliform yang terdapat pada keju nabati ditunjukkan pada Tabel 5.

Bakteri asam laktat merupakan bakteri yang digunakan untuk menggumpalkan protein pada fermentasi susu kedelai. Banyaknya populasi bakteri asam laktat dipengaruhi oleh adanya ketersediaan substrat (Usmiati et al., 2011) pada media tumbuhnya. Menurut Charterist et al. (1998), produk yang tergolong pada produk probiotik dan dapat memberikan manfaat pada kesehatan memiliki jumlah sel bakteri hidup $10^{7}-10^{8} \mathrm{cfu} / \mathrm{g}$. Produk keju nabati yang dihasilkan tidak tergolong pada produk probiotik. Adanya pertumbuhan bakteri asam laktat menandakan bahwa fermentasi masih berlangsung pada keju nabati. Keju pada umumnya akan mengalami fermentasi selama seminggu, namun pada tipe keju seperti keju cheddar telah mengalami proses fermentasi yang lengkap sebelum pengepresan (Nip, 2007).

Penghitungan bakteri koliform yang dilakukan yang menggunakan media Eosin Methylene Blue (EMB) menunjukkan bahwa tidak terdapat bakteri koliform pada keju nabati yang dihasilkan. Hal ini menunjukkan bahwa sanitasi dan proses pengolahan dalam keadaan yang cukup baik, sehingga tidak ditemukan bakteri pencemar di dalam produk. Karakteristik mikrobiologis ini telah sesuai dengan SNI keju cheddar olahan.

\section{KESIMPULAN DAN SARAN}

\section{Kesimpulan}

Formulasi terbaik dalam pembuatan keju nabati adalah menggunakan bahan baku susu kedelai segar dengan inokulum $15 \%$ dan bahan tambahan pangan berupa perisa keju dengan konsentrasi $0,9 \%$. Formulasi tersebut telah menghasilkan keju nabati yang menyerupai aroma pada keju susu hewani komersial. Keju nabati yang dihasilkan memiliki karaktertistik kadar air dan kadar abu yang sama dengan keju nabati berbahan baku susu kedelai bubuk, namun berbeda pada kadar protein dan kadar lemak. Kategori dari keju nabati yang dihasilkan adalah keju sami keras (semi hard cheese) berdasarkan nilai MFFB dan tergolong skim cheese berdasarkan nilai DFM.

Tabel 4. Hasil analisis komposisi nutrien keju nabati

\begin{tabular}{|c|c|c|c|c|}
\hline Pengujian & $\begin{array}{c}\text { Susu Kedelai Segar, } \\
\text { Inokulum 15\%, perisa } \\
0,7 \%\end{array}$ & $\begin{array}{c}\text { Susu Kedelai Segar, } \\
\text { Inokulum } 15 \% \text {, } \\
\text { perisa0,9\% }\end{array}$ & $\begin{array}{c}\text { Susu Kedelai } \\
\text { Bubuk, Inokulum } \\
15 \%, \text { perisa } 1,3 \% \\
\end{array}$ & SNI* \\
\hline Kadar air (\%) & $62,84 \pm 0,97 \mathrm{a}$ & $66,30 \pm 0,30 \mathrm{~b}$ & $67,18 \pm 0,11 b$ & $<45 \%$ \\
\hline Kadar abu $(\%)$ & $3,42 \pm 0,01 \mathrm{a}$ & $3,27 \pm 0,1 \mathrm{a}$ & $3,71 \pm 0,03 \mathrm{a}$ & $<5,5 \%$ \\
\hline Kadar protein $(\%)$ & $27,02 \pm 1,00 \mathrm{a}$ & $26,74 \pm 1,13 a$ & $20,62 \pm 1,63 b$ & $>19,5 \%$ \\
\hline Kadar lemak (\%) & $0,36 \pm 0,02 \mathrm{a}$ & $0,36 \pm 0,02 \mathrm{a}$ & $0,14 \pm 0,01 \mathrm{a}$ & $>25 \%$ \\
\hline FDM $(\%)$ & $0,36 \pm 0,02 \mathrm{a}$ & $0,36 \pm 0,02 \mathrm{a}$ & $0,14 \pm 0,01 \mathrm{a}$ & $>25 \%$ \\
\hline MFFB (\%) & $63,07 \pm 0,99 \mathrm{a}$ & $66,53 \pm 0,28 b$ & $67,28 \pm 0,10 \mathrm{~b}$ & - \\
\hline
\end{tabular}

${ }^{a}$ Angka-angka pada kolom yang sama yang diikuti oleh huruf yang sama tidak berbeda nyata pada taraf uji 5\% (uji selang berganda Duncan).

FDM : fat content in dry matter

MFFB : moisture free fat basis

Sumber : * SNI Keju Cheddar Olahan (SNI 01-2980-1992)

Tabel 5. Populasi BAL dan bakteri koliform pada non-dairy cheese

\begin{tabular}{|c|c|c|c|c|}
\hline Pengujian & $\begin{array}{c}\text { Susu Kedelai } \\
\text { Segar, Inokulum } \\
15 \% \text {, perisa } 0,7 \% \\
\end{array}$ & $\begin{array}{c}\text { Susu Kedelai Segar, } \\
\text { Inokulum } 15 \% \text {, } \\
\text { perisa } 0,9 \% \\
\end{array}$ & $\begin{array}{c}\text { Susu Kedelai } \\
\text { Bubuk, Inokulum } \\
\text { 15\%, perisa 1,3\% } \\
\end{array}$ & SNI* \\
\hline Populasi BAL $\left(\log \mathrm{cfu} \mathrm{g}^{-1}\right)$ & $5 \pm 0$ & $5,33 \pm 0,01$ & $6,41 \pm 0,02$ & - \\
\hline $\begin{array}{l}\text { Jumlah Bakteri Koliform } \\
\left(\log \mathrm{cfu} \mathrm{g}^{-1}\right)\end{array}$ & $\mathrm{Td}$ & $\mathrm{Td}$ & $\mathrm{Td}$ & $\mathrm{Td}$ \\
\hline $\begin{array}{r}\text { Keterangan : Td : tidak terdeteks } \\
\text { BAL : Bakteri Asa } \\
\text { Sumber } * \text { SNI Keiu Cheddar }\end{array}$ & $\begin{array}{l}\text { tat } \\
\text { (SNI 01-2980-1992) }\end{array}$ & & & \\
\hline
\end{tabular}


Saran

Perlu dilakukan penelitian lebih lanjut mengenai pengaruh pemeraman terhadap karakteristik keju nabati, umur simpan dari produk yang dihasilkan serta analisis finansial.

\section{DAFTAR PUSTAKA}

[AOAC] Association of Official Analytical Chemist. 1995. Official Method of Analysis of The Association of Official Analytical of Chemist. Washington DC (US) : AOAC .

[AOAC] Association of Official Analytical Chemist. 2005. Official Method of Analysis of The Association of Official Analytical of Chemist. Arlington (US): AOAC.

[BSN] Badan Standardisasi Nasional. 1992. SNI 012980-1992. Keju Cedar Olahan. Jakarta (ID): BSN.

[BSN] Badan Standardisasi Nasional. 1995. SNI 013830-1995. Susu Kedelai. Jakarta (ID): BSN.

[BSN] Badan Standardisasi Nasional. 2004. SNI 066989.27:2004. Air dan Limbah-Cara Uji Kadar Padatan Terlarut Total, Total Dissolved Solid (TDS) Secara Gravimetri. Jakarta (ID): BSN.

[CAC] Codex Alimentarius Commission. 1978. CODEX General Standard for Cheese. CODEX STAN 283-1978 [internet]. [diacu 2016 Juli 28]. Tersedia pada : http://www.fao.org/input/download/standard s/175/CXS_283e.pdf.

Ahmad N, Li L, Yang X, Ning Z, Randhawa MA. 2008. Improvements in the flavour of Soy Cheese. Food Technol. Biotechnol. 46 (3) 252-261.

Al-kotami S, Abou-Ghorrah S, dan Yazaji S. 2015. Detection and isolation of lactic bacteria and its use as local starters in Syrian Akawi cheese processing. International Food Research Journal 22(4): 1699-1704 (2015).

Alveanita M. 2016. Susu Sapi Vs Susu Kedelai. [internet Tersedia pada : http://www.pekalongankab.go.id/informasi/a rtikel/pertanian/8222-susu-sapi-vs-susukedelai.html. ]. [2016 Agustus 1].

Anonim. 2016. Keju Bukan 'Musuh' Diet Anda. Di dalam : Pesona. [internet]. Tersedia pada : http://www.pesona.co.id/article/keju-bukan-musuh--diet-anda. [2016 Agustus 1].

Ariani SRD. 2002. Pembuatan keju kedelai yang mengandung senyawa faktor-2 hasil biokonversi isoflavon pada tahu oleh Rhizopus Oligosporus. Biosmart. 5 (1): 8-12.

Arinda AF, Sumarmono J, dan Sulistyowati M. 2013. Pengaruh bahan pengasam dan kondisi susu sapi terhadap hasil/rendemen, keasaman, kadar air dan ketegaran (firmness) keju tipe mozarella. Jurnal Ilmiah Peternakan. 1 (2) :455-462.
Atia W, Wenshui X, dan Gunong Z. 2004. Effect of soy protein supplementation on the quality of ripening Cheddar-type cheese. International Journal of Dairy Technology 57 (4).

Charterist WP, Kelly PM, Morelli L, Collins JK. 1998. Ingredient selection criteria for probiotics microorganism in functional dairy foods. International Journal of Dairy Technology. 51 (4) : 4121-4128.

Chumcuere S, macDougall BD, dan Robinson RK.2000. Production and properties of semi hard cheese made from soya milk. Journal of Food Science and Technology 35:577-581.

Dahana K dan Wahino 2010. Meraup Untung dari Olahan Kedelai. Jakarta (ID) : PT Agromedia Pustaka.

Deliani. 2008. Pengaruh lama fermentasi terhadap kadar protein, lemak, komposisi asam lemak dan asam sitrat pada pembuatan tempe. [Tesis]. Sumatera Utara: Universitas Sumatera Utara.

Ernawati UR, Khasanah LU, dan Anandito RBK. 2014. Pengaruh variasi nilai Dextrose Equivalent (DE) terhadap karakteristik mikroenkapsulan pewarna alami daun jati (Tectona Grandis L.f.). Jurnal Teknologi Pertanian. 15(2): 111-120.

Hofman DL, Buul VJ, dan Brouns FJPH. 2016. Nutrition, health, and regulatory aspects of disgetible maltodextrins. Critical Reviews in Food Science and Nutrition 56:12, 20912100.

Hati S, Vij S, Mandal S, Malik RK, Kumari V, dan Khetra Y. 2012. A-galaktosidase Activity and oligosaccharides utilization by lactobacilli during fermentation of soy milk. Journal of Food Processing and Preservation. 38 (3): 1065-1071.

Herawati H. 2011. Peluang Pemanfaatan Tapioka Termodifikasi Sebagai Fat Replacer pada Keju Rendah Lemak. Seminar Nasional Teknologi Peternakan dan Veteriner. Bogor: Balai Besar Penelitian dan Pengembangan Pascapanen Pertanian.

Juniawati, Usmiati S, dan Damayanthi E. 2015. Karakter/ sifat fisik kimia keju rendah lemak dari berbagai bahan baku susu modifikasi. Jurnal Penelitian Pascapanen Pertanian.12 (2) : 28-36.

Li Q, Xia Y, Zhou L, Xie J. 2013. Evaluation of rheological, textural, microsructural and sensory properties of soy cheese spreads. Food and Bioproducts Processing. 91 : 429439.

Lin C. 2010. Rheological characteristic, microstructure, and cheese making properties of mixed soy milk gels. [Thesis] Canada: University of Guelph. 
Fox PF, McSweeney PLH, Cogan TM, Guinee TP. 2004. Cheese : Chemistry, Physics, and Microbiology. Italy (IT) : Elsevier Academic Press.

Makfoeld D, Marseno DW, Hastuti P, Anggrahini S, Raharjo S, Satrosuwignyo S, Suhardi, Martoharsono S, Hadiwiyoto S, dan Tranggono. 2002. Kamus Istilah Pangan dan Nutrisi. Yogyakarta (ID) : Penerbit Kanisius

Melito HS, Daubert CR, dan Foegeding EA. 2013. Relationship between nonlinear viscoelatic behavior and rheological, sensory, and oral processing behavior of commercial cheese. Journal of Texture Studies. 44(4).

Miskiyah, Usmiati S, dan Mulyorini. 2011. Pengaruh enzim proteolitik dengan bakteri asam laktat probiotik terhadap karakteristik dadih susu sapi. Jurnal Ilmu Ternak dan Veteriner. 16 (4): 304-311.

Mullan WMA. 2007. Case study-reduced cheese yields in a commercial Cheddar cheese factory. [internet]. [16 Agustus 2016]. Tersedia pada: https://www.dairyscience. info/index.php/cheese-yield/113-case-studyreduced-cheese-yields-in-a-commercialcheddar-cheese-factory.html .
Nip WK. 2007. Handbook of Food Manufacturing. California (US) : J. Wiley.

Peacock P. 2010. Making Your Own Cheese : How to Make All Kinds of Cheese in Your Own Home. Oxford (UK) : Spring Hill.

Setyaningsih D, Apriyantono A, dan Sari MP. 2010. Analisis Sensori untuk Industri Pangan dan Agro. Bogor (ID) : PT Penerbit IPB Press.

Simanjuntak TPT. 2014. Buku Komponen Gizi dan Terapi Ala Papua. Yogyakarta (ID) : Deepublish.

Speer E. 1998. Milk and Dairy Product Technology. New York (US) : Marcal Dekker Inc.

Usmiati S dan Risfaheri. 2013. Pengembangan dadih sebagai pangan fungsional probiotik asli sumatera barat. Jurnal Litbang Pertanian. 32 (1): 20-29.

Usmiati S, Broto W, dan Setiyanto H. 2011. Karakteristik dadih susu sapi yang menggunkan starter bakteri probiotik. Jurnal Ilmu Ternak dan Veteriner. 16 (2): 140-152.

Yusmarini, Indrati R, Utami $\mathrm{T}$, dan Marsono Y. 2010. Aktivitas proteolitik bakteri asam laktat dalam fermentasi susu kedelai. Jornal Teknologi dan Industri Pangan, XXI (2): Th. 2010. 